\title{
Effects of Improved Cassava Varieties on Farmers' Income in Northern Agro-ecological Zone, Uganda
}

\author{
Graceline O. Akongo ${ }^{1}$, Godfrey A. Otim ${ }^{1}$, Laban F. Turyagyenda ${ }^{1}$, Anton Bua ${ }^{1}$, Alfred Komakech ${ }^{2} \&$ S. Obong ${ }^{1}$ \\ ${ }^{1}$ National Agricultural Research Organization (NARO), P. O. Box 295, Entebbe, Uganda \\ ${ }^{2}$ Project for the Restoration of Livelihoods in Northern Region (PRELNOR), Gulu, Uganda \\ Correspondence: Graceline O. Akongo, Ngetta Zonal Agricultural Research and Development Institute, P.O. Box \\ 52, Lira, Uganda. Tel: 256-772-342-974. E-mail: gracelinako@gmail.com
}

Received: December 22, 2020 Accepted: April 1, $2021 \quad$ Online Published: April 10, 2021

doi:10.5539/sar.v10n2p65 URL: https://doi.org/10.5539/sar.v10n2p65

\begin{abstract}
This paper examines the extent to which improved cassava varieties contribute to improvement in income of smallholder farmers in the Northern agro-ecological zone of Uganda. In order to achieve the objective, data was collected from PRELNOR supported farmers' fields, other farmers' fields and baseline cassava fields. Consequently, descriptive statistics, gross margin and stochastic frontier analysis were adopted during analysis. Results from the analysis revealed that higher yields per hectare were registered within PRELNOR supported farmers' fields and yield from NAROCAS1 surpassed all the varieties (37.3 tons per hectare). Location specific results revealed that Gulu had better yields (34.5 tons per hectare) while Kitgum registered the lowest average yield (24.1 tons per hectare). Gross margin indicated that every Shilling invested in improved variety earned profit 1.3 to 1.8 times above the local variety and each shillings invested in PRELNOR supported fields generated 5.6 times above the baseline fields. The parameter estimate for profit function revealed that planting material, other production related costs, NAROCAS1, NASE14 and NASE19 were positively correlated with profit but labour and baseline field had negative correlations. Conversely, profit efficiency grew by $40 \%$ under improved varieties against local varieties. This study suggests that the difference in yields and profit between locations was caused by biophysical characteristic; disease tolerant varieties can tremendously improve profitability and income; meanwhile the profit gaps were partly attributed to inefficiency. This study recommends fast tracking adoption of pest and disease tolerant varieties and integrated research and development approach throughout the cassava value chain.
\end{abstract}

Keywords: cassava, income, Northern Uganda, profit efficiency, yield

\section{Introduction}

Cassava is grown and consumed throughout the world as a cheap source of carbohydrates, food security and income crop. In Uganda, it is the major root crop and is grown and consumed throughout the country (Kilimo Trust, 2012; Buyinza \& Kitinoja, 2018; NARO, 2018; UBOS, 2019). Accordingly, area planted with the crop increased from 401,000 hectares in 2000 to 794,000 during 2010 then to 881,040 by 2018 (UBOS, 2003, 2011, 2019). This therefore makes Uganda the sixth and first largest producer of cassava in Africa and east Africa, respectively (Kilimo Trust, 2012). Consequently, the crop has graduated to constitute part of the 16 major food crops grown in the country according to the Uganda Census of Agriculture (UCA) 2008/09 (UBOS, 2010). According to the cassava vision Africa, the crop is expected to contribute to food security and incomes for value chain actors thus promoting rural development. Within Uganda, northern region is the second largest producer of the crop accounting for 34\% after eastern region (UBOS, 2010). However, its production in the region has been constrained by the two decades of civil war, poor weather, lack of quality planting material, poor management practices and pests and diseases. Cassava mosaic disease (CMD) and cassava brown streak disease (CBSD) have been the most constraining diseases. A number of released varieties before 2015 including TME14, TME204 and NASE13 among others succumbed to CMD and CBSD (Okao-Okuja et al., 2017). At the national level, total production declined persistently from 4,966,000 tons during 2000 to 3,017,000 tons during 2010 then to $2,819,327$ tons as of 2018. Yield has also been on the decline from 12.4 tons per hectare in 2000 down to 3.8 tons in 2010 and then 3.2 during 2018. Potential yields of cassava attainable under good management ranged between 40.5 and 50.6 tons per hectare (Buyinza \& Kitinoja, 2018). In northern region (Acholi sub region) 
farmers only get a tenth (5 tons per hectare) of the expected average (Akongo \& Otim, 2017). Poor per unit performance of the crop has subsequently affected both food and income security of the farmers in the region.

Consequently, PRELNOR through Ngetta Zonal Agricultural Research and Development Institute (Ngetta ZARDI) which is one of the National Agricultural Research Organisation (NARO) institutes, selected, adapted and promoted high yielding and disease resistant varieties and practices. Among the varieties adapted and promoted were NASE14, NASE19 and NAROCAS1. Although yields from these varieties were high, the biggest challenge beforehand was limited knowledge on the extent to which these varieties were translating into improvement in farmers' income. It was against this background that this paper sought to examine the extent to which these varieties were contributing to farmers' income while using Acholi subregion of the northern agro-ecological zone as a case.

\section{Methods}

\subsection{Study Area}

Acholi subregion forms part of the northern agro-ecological zone (NAEZ) located in the northern region of Uganda (Figure 1). The NAEZ lies between Latitude $03^{\circ} 80^{\prime} \mathrm{N}$ and Longitude $33^{\circ} 00^{\prime} \mathrm{E}$ with elevations varying between 600 and 1,200 meters above sea level (JICA, 2012). The subregion is particularly bordered by South Sudan in the north, Lango subregion in the south, West-Nile and Lake Albert Crescent in the west and Karamoja subregion in the east. The subregion has got 8 districts including Gulu, Amuru, Nwoya, Omoro, Kitgum, Lamwo, Pader and Agago. The subregion has a total area of $28,278 \mathrm{~km}^{2}$ (11.7\% of the total land area in Uganda) and a total population of 1,5 million people of whom women constitute $51.5 \%$ (UBOS, 2019). The study area was chosen because it had the lowest per unit yield (Akongo \& Otim, 2017; UBOS, 2010). Secondly, it was where the high yielding and pest and disease resistant cassava varieties were widely adapted and promoted during the past three years under PRELNOR.

The area is categorized by tropical dry climate with bimodal to unimodal rainfall patterns with long-term average of $1434 \mathrm{~mm}$ (Akongo et al., 2018; JICA, 2012). However, a noticeable reduction in amount, intensity and duration occurs in the north and eastern districts.

Acholi_Region_Districts

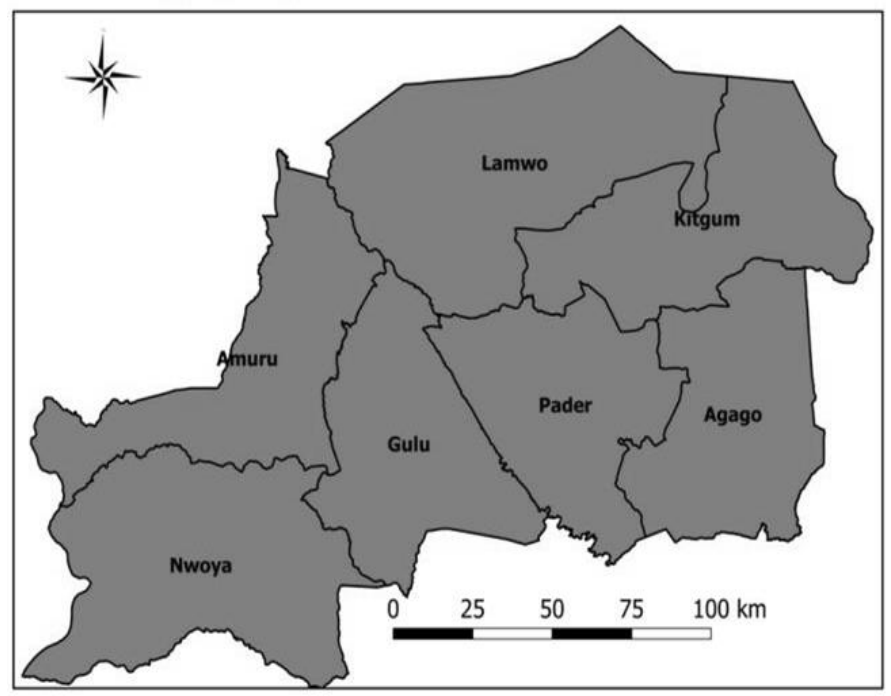

Figure 1. Map of Acholi sub-region showing PRELNOR districts

The temperature ranges between $17^{\circ} \mathrm{C}$ and $32^{\circ} \mathrm{C}$ and this explains high prevalence of cassava in the area since root production is maximized between 25 and $32^{\circ} \mathrm{C}$ (UNMA, 2017; Buyinza \& Kitinoja, 2018; UBOS, 2019). The soil type is Ferralsols though some patches of Leptosols and Plinthosols are of common occurrence (Akongo et al., 2018). Leptosols is characterized by many coarse fragments (sandy-clay) which renders it less productive in terms of crop growth (IUSS Working Group WRB, 2015). Unlike the rest of other crops, cassava adapts to marginal soil conditions. In terms of economic activities, agriculture is the backbone of the regional economy and more than $80 \%$ of the population is engaged in subsistence farming for food and earn their income from sale of crops. 


\subsection{Data Collection}

This paper adopted exploratory designs and the research approach was quantitative. The study population consisted of fields planted with cassava. Data was collected from a total sample of 392 fields. A sample of 137 constituted PRELNOR supported fields, 158 were other farmers' fields (other farmers' fields where those planted with cassava within proximity of PRELNOR area but not supported by PRELNOR) while 97 were baseline fields (these where fields from which data were collected during the PRELNOR baseline survey conducted in 2017). Two sets of data were collected: The first data set were collected during baseline survey in 2017 while the second data set were collected in 2020. The production data included yield, cost of inputs and cassava sale prices. The cost and price data were based on the current market cost of cassava production per hectare and price of fresh root tubers per kilogram, respectively. Inkind costs were excluded and the actual costs together with the price of fresh root were later used to compute revenue and profit. This study operationally defines income in terms of profits (gain or loss) made from investment in cassava production by the farmers, and hence financial gains accruing to individual or household as a result of applying the improved technologies.

\subsection{Data Analysis}

Three forms of analysis were applied to achieve the study objective: descriptive statistics, gross margin and stochastic frontier analysis. Descriptive statistics was used to generate means, standard deviation, frequencies and percentages. Gross margin is the difference between the gross farm income (total revenue) and the total variable cost (Ezeano et al., 2017; Isonguyo \& Omolehin, 2017; Itam et al., 2014, 2018). The analysis performed to estimate returns (profitability) was given as;

$$
G M=T R-T V C
$$

Where;

$G M=$ Gross margin

$T R=$ Total Revenue (Price*Quantity)

$T V C=$ Total variable cost (variable costs are costs which change as output changes).

Profit efficiency: to earn profit, resources (costs are incurred) are used to generate some level of output and hence profitability is a measure of the relationship between profits earned and resources used to earn profits (It is influenced by the margins between per unit costs and returns). In essence, profitability is closely related to efficiency (profit efficiency). In order to examine this relationship, stochastic frontier analysis was performed (Akongo et al., 2016; Belotti et al., 2012; Hyuha et al., 2007). The model helps to account for inefficiency component separately from measurement error and other statistical noise in a survey data. Accordingly, a stochastic profit function was constructed using Cobb-Douglas functional form (equation2).

Where

$$
\ln \pi=a_{0}+a_{0}+\sum_{i=1}^{4} a_{i} p_{i}+\sum_{i=1}^{4} a_{i} w_{i}+v_{i}-u_{i}
$$

$\pi=$ restricted normalized profit defined as gross revenue less variable costs divided by tuber price per kilogram (p)

$\mathrm{p}_{\mathrm{i}}=$ Costs of variable inputs normalised by price of root tuber.

Where,

$\mathrm{p}_{1}=$ total cost per hectare,

$\mathrm{p}_{2}=$ cost of planting material,

$\mathrm{p}_{3}=$ cost of labour inputs,

$\mathrm{p}_{4}=$ other costs,

$\mathrm{w}_{\mathrm{i}}=$ dummies for cassava varieties and period.

Where,

$\mathrm{w}_{1}=$ Type of variety ( $1=\mathrm{NAROCAS} 1 ; 0=$ Otherwise) - priori assumption (positive relationship)

$\mathrm{w}_{2}=$ Type of variety ( $1=$ NASE14; $0=$ Otherwise) - priori assumption (positive relationship)

$\mathrm{w}_{3}=$ Type of variety (1=NASE19; $0=$ Otherwise) - priori assumption (positive relationship)

$\mathrm{w}_{4}=$ Category $(1=$ Baseline fields; $0=$ Otherwise) - priori assumption (negative relationship)

Throughout the analysis, local varieties and baseline fields were used as the controls against improved varieties 
and PRELNOR supported farmers' fields, respectively

\section{Results and Discussion}

The result sections reports yields, gross margins, parameters of the profit function and efficiency scores. Throughout the sections, results are reported according to the field category (baseline fields, other farmers' field and PRELNOR supported fields), locations (Gulu, Amuru, Kitgum and Agago districts) and varieties (Local, NAROCASI, NASE14 and NASE19). Standard units of measurement are used: cassava yields are provided in tons per hectare, cost of production and profits per hectare were provided in Ugandan Shilling (exchange rate for Uganda shillings against US Dollar was valued at Ugx 3,700/-) and prices of fresh root tubers are given in shillings per kilogram.

\subsection{Yield Performance}

Mean yields are provided by field category, location and varieties in tons per hectare (Table 1). For each field category, variations between the baseline fields, other farmers' field and PRELNOR supported fields were observed. Cassava yielded highest (28 tons) in PRELNOR supported fields which was above the baseline average (6.1 tons) and other farmers' field (11.1 tons), respectively. The PRELNOR supported fields were within the range of expected potential yield under good management practices which ranges between 25 and 45 tons per hectare (Okao-Okuja et al., 2017). Generally, significant differences among field categories were mainly attributed to good agronomic practices and quality planting materials promoted under PRELNOR.

With respect to locations, yields varied significantly between the districts where higher yield averages were achieved in Gulu (34.5 tons) followed by Amuru (26.5 tons). However, Kitgum (24.1 tons) and Agago (24.3 tons) realised lower averages. The possible explanation for yield variations between locations is differences in biophysical characteristics (soil and climate). It is evidently clear that certain conditions within the locality of the eastern districts do not favour production compared to the western districts which attained higher averages.

In regards to varieties, lower average was achieved under local variety (Bao variety) as expected (20.1 tons). On the contrary, higher yields per hectare were obtained under improved varieties with NAROCAS1 (37.3 tons) surpassing NASE14 (28.1 tons) and NASE19 (26.9 tons). Although there were yield variations between locations and varieties, still there were significant improvements above the baseline fields and average registered elsewhere in western region of the country for NASE14 ( 22 tons). Generally, all the improved varieties promoted by PRELNOR performed within the range of the expected yield potential under good management practices. Buyinza \& Kitinoja (2018) reported national average yield of cassava in Uganda at 12.65 tons per hectare. However, yield potential attainable in the country under good management conditions and practices ranges between 25 and 45 tons per hectare depending on a variety (Okao-Okuja et al., 2017). Whereas in other countries like Nigeria, potential yield averages under local variety ranges between 20 and 30 tons per hectare, under improved varieties is 25 to 70 tons per hectare and under marginal conditions where other crops fail is between 8 and 15 tons per hectare.

Table 1. Yield (tons) per hectare

\begin{tabular}{llllll}
\hline & Obs & Mean & Std. Dev. & Min & Max \\
\hline Field category & & & & & \\
Baseline fields & 97 & 6.1436 & 5.7636 & 0.4708 & 31.6384 \\
Other fields & 158 & 11.1177 & 12.5118 & 4.1667 & 64.501 \\
PRELNOR supported fields & 137 & 28.0111 & 13.5156 & 5 & 62.1469 \\
Location & & & & & \\
Agago & 44 & 24.2926 & 13.1201 & 5 & 57.9096 \\
Kitgum & 24 & 24.076 & 13.3497 & 5 & 48.4934 \\
Amuru & 24 & 26.5214 & 8.5961 & 14.9434 & 45.0752 \\
Gulu & 45 & 34.5402 & 14.0545 & 9.8587 & 62.1469 \\
Variety & & & & & \\
Local & 35 & 20.8409 & 9.7232 & 5 & 62.1469 \\
NASE14 & 36 & 28.1033 & 9.7268 & 14.9434 & 57.9096 \\
NASE19 & 35 & 26.874 & 14.686 & 5 & 57.9096 \\
NAROCAS1 & 31 & 37.2832 & 14.6906 & 5 & 57.9096 \\
\hline
\end{tabular}




\subsection{Income Analysis}

\subsubsection{Change in Profit}

Profits are computed on per hectare basis and the results are provided in Uganda shillings while investment effects are provided against the baseline and local variety (Table 2). The baseline fields registered lower per unit profit of 2,519,209/- shillings. Other farmers' field obtained 5,454,677/- shillings while PRELNOR supported fields generated 14,200,000/- shillings. Comparatively, investment effect from PRELNOR supported fields was 5.6 times above the baseline fields. By implication, profit could improve by 5.6 times above the baseline fields for every 1 shilling invested. Likewise for every 1 shilling invested in other farmers' fields, the return to investment was 3.1 times above the baseline fields. In fact, returns to investment (profit) within PRELNOR supported fields also surpassed 4,861,850/- shillings per hectare obtained elsewhere (AgriTT, n.d.). This could be explained by exposure and knowledge on good agronomic practices obtained by the farmers through trainings and information exchange under PRELNOR. Investment effects from other farmers' fields were 2.2 times the baseline fields and this could have been a result of spillover effects from PRELNOR.

Table 2. Revenue, profit and investment effect per hectare

\begin{tabular}{lllllll}
\hline & Revenue & \multicolumn{2}{l}{ Profit (shilling) per hectare } & \multirow{2}{*}{ Investment effects } \\
\cline { 1 - 5 } & & Mean & Std. Dev. & Min & Max & \\
\cline { 1 - 5 } Field category & & & & & & \\
Baseline fields & $3,262,267$ & $2,519,209$ & $3,075,843$ & 150,000 & $16,300,000$ & \\
Other fields & $5,903,475$ & $5,454,677$ & $6,283,513$ & $1,389,500$ & $32,500,000$ & 2.17 \\
PRELNOR & $14,900,000$ & $14,200,000$ & $7,134,750$ & $1,970,055$ & $32,500,000$ & 5.64 \\
supported fields & & & & & & \\
Variety & & & & & & \\
Local & $11,100,000$ & $10,600,000$ & $5,161,140$ & $2,170,055$ & $32,500,000$ & \\
NASE14 & $14,900,000$ & $14,200,000$ & $5,159,230$ & $7,250,000$ & $30,000,000$ & 1.34 \\
NASE19 & $14,300,000$ & $13,600,000$ & $7,783,921$ & $1,970,055$ & $30,000,000$ & 1.28 \\
NAROCAS1 & $19,800,000$ & $19,100,000$ & $7,769,297$ & $1,970,055$ & $30,000,000$ & 1.80 \\
\hline
\end{tabular}

The improved varieties performed better than the local varieties with NAROCAS1 surpassing all the other varieties. NAROCAS1 generated profit worth 19,100,000/- shillings, NASE14 had 14,200,000/- shillings and NASE19 was the least among improved varieties with 13,600,000/- shillings. In terms of the investment effects, every shillings investment in NAROCAS1 variety would translate into income improvement worth 1.8 times above the local variety. Similarly NASE14 and NASE19 were 1.34 and 1.28 times that of local variety, respectively. Generally, every 1 shilling invested in improved variety increase farmers' income by 1.3 to 1.8 times (investment effects) above the local varieties. This is a confirmation that having access to improved varieties is a strategy towards improving farm household income and poverty reduction. Similar results have been reported elsewhere. In Nigeria, Akerele et al. (2019) reported benefit/cost ratio of $1.99 \mathrm{k}$ which suggested that every $1 \mathrm{k}$ invested in cassava production could realize $99 \mathrm{k}$ as a profit. Isonguyo \& Omolehin (2017) observed similar result where an average rate of return of CMD resistant variety was higher at 2.49 against 1.67 for non-CMD resistant variety. Itam et al. (2014) found cassava production profitable with a gross margin of \$9,520.66 per hectare. Likewise a_study by Omotayo \& Oladejo (2016) revealed that cassava is profitable according to the gross margin analysis but its net return was being affected negatively by cost of labuor and cassava planting material._Meanwhile (Ndonda et al., 2015) found that local varieties of cassava performed poorly and less profitable under intercropping system in DRC. These results were confirmed by the finding in this study that improved varieties are more profitable than non-improved varieties.

\subsubsection{Profit Function}

The results obtained through gross margin analysis confirmed that cassava production was profitable and indeed it contributes to improvement in farmers' income. However, additional analysis was conducted to ascertain whether resources are being utilized efficiently (cost minimization) given the current level of profit (Akongo et al., 2016; Belotti et al., 2012; Hyuha et al., 2007). Consequently, stochastic profit function was estimated and the results of the parameter estimates are presented in Table 3. All the estimated parameters to explain the current level of profit were statistically significant except total cost of production and cost of labour used in production. Joint test for the variables was statistically different from zero $\left(\mathrm{chi}^{2}{ }_{(8)}=463.02\right.$; Prob $\left.>\mathrm{chi}^{2}=0.000\right)$. The result confirmed the priori expectation for all the variables in terms of the sign of the coefficient. Return to scale from investing in direct variable costs was on the decrease (RTS of 0.6) implying that the current level of profit is not 
economically viable. Interestingly, the RTS could be enhanced to 1.3 when improved varieties are used and therefore economically viable.

The estimated coefficients for the normalized profit function assume competitive market price in the cassava industry. The coefficient of variable cost of planting material was positive and significant at $1 \%$ level and by implication profit could increase with a unit increase in cost at the current level of production. In Nigeria, Itam et al. (2018) reported range similar to this study (22\%) for cost of cuttings to total costs of production. However, in a related study the same authors observed contrary result where planting material had an inverse relationship with output (Itam et al., 2014). Ezeano et al. (2017) reported cost of cuttings at 37\% of the total input cost in Nigeria. Other costs of production had a strong positive bearing on profit implying that a unit increase in other costs would translate in improvement in profit by approximately 43\%. According to the authors, it was economical for farmers to increase their scale of production to match the current cost level.

Table 3. Maximum likelihood estimates of the parameters

\begin{tabular}{|c|c|c|c|c|c|c|}
\hline & & & Number of ol & & $=$ & 392 \\
\hline & & & Wald chi2(8) & & $=$ & 463.02 \\
\hline Log likelihood & -476.2627 & & Prob $>$ chi 2 & & $=$ & 0 \\
\hline lnProfit & Coef. & Std. Err. & $\mathrm{z}$ & $\mathrm{P}>\mathrm{Z}$ & {$[95 \%$ C.I } & \\
\hline lnTotal Cost & -0.0863 & 0.0960 & -0.9 & 0.369 & -0.2745 & 0.1020 \\
\hline lnplanting material & 0.2660 & 0.0989 & 2.69 & 0.007 & 0.0720 & 0.4599 \\
\hline lnLabour cost & -0.0136 & 0.0834 & -0.16 & 0.87 & -0.1771 & 0.1498 \\
\hline lnOther costs & 0.4264 & 0.0724 & 5.89 & 0 & 0.2845 & 0.5682 \\
\hline NAROCAS1 & 0.5650 & 0.1390 & 4.06 & 0 & 0.2924 & 0.8375 \\
\hline NASE14 & 0.3776 & 0.1488 & 2.54 & 0.011 & 0.0859 & 0.6693 \\
\hline NASE19 & 0.4263 & 0.1504 & 2.83 & 0.005 & 0.1315 & 0.7211 \\
\hline Baseline & -0.6950 & 0.1132 & -6.14 & 0 & -0.9168 & -0.4732 \\
\hline _cons & 6.9034 & 0.2816 & 24.52 & 0 & 6.3515 & 7.4552 \\
\hline /lnsig2v & -2.7625 & 0.3081 & -8.97 & 0 & -3.3664 & -2.1586 \\
\hline$/ \operatorname{lnsig} 2 u$ & 0.7015 & 0.0942 & 7.45 & 0 & 0.5169 & 0.8861 \\
\hline sigma_v & 0.2513 & 0.0387 & & & 0.1858 & 0.3398 \\
\hline sigma_u & 1.4201 & 0.0669 & & & 1.2949 & 1.5575 \\
\hline sigma 2 & 2.0799 & 0.1824 & & & 1.7224 & 2.4374 \\
\hline lambda & 5.6520 & 0.0906 & & & 5.4744 & 5.8295 \\
\hline
\end{tabular}

Using improved varieties confirmed priori assumption that it would enhance profit. NAROCAS1 had the highest positive response to profit (1\% level of significance) and similarly planting NASE19 and NASE14 significantly improves profit implying that planting the varieties results in an increment in profit. Results from this study are in agreement with studies by Ndonda et al. (2015) who observed that the choice of cassava variety determines profitability of a cropping system. Ndonda et al. (2015) further found low efficiency associated with local cassava variety and concluded that improved varieties that are more productive and increase the net income and thus provide an economic benefit. Again this confirms (Itam et al., 2018) that improved cassava varieties are more profitable. As expected, lower profits generated from the baseline fields did not come as a surprise. Generally, there was a significant reduction in profit from the baseline fields. This relationship is best explained by the fact that farmers were growing low yielding and disease susceptible varieties and were less equipped with knowledge in good management practices before the project was introduced (Akongo \& Otim, 2017).

However, there were no significant results for total costs and labour costs to warrant further discussion. Nevertheless, the inverse relationship depicted meant profit level decreases with costs. Although the cost of labour was not statistically significant, the result indicated negative effect on profit and hence farmers' income. Elsewhere, labour has been found to be a constraining input factor in cassava production (AgriTT, n.d.). Besides its cost implication, failure to have timely access can compromise quick and timely operations to catch up with rains. In Itam et al. (2018), cassava production in Nigeria was reported profitable but labour costs was found to constrain profit.

\subsubsection{Efficiency Gain and Loss}

The variance of inefficiency effect $\left(\sigma_{v}^{2}\right)$ was large suggesting that $97 \%$ (gamma) of variation in profit were due to inefficiency. Consequently, further investigation was conducted to identify inefficiency gaps and source of profit gains and lose (Figure 2). The result revealed that there was a huge inefficiency gap between the actual and 
the best profit frontier. Comparison of inefficiency performance between the baseline, PRELNOR supported and other fields also revealed some degree of variations.

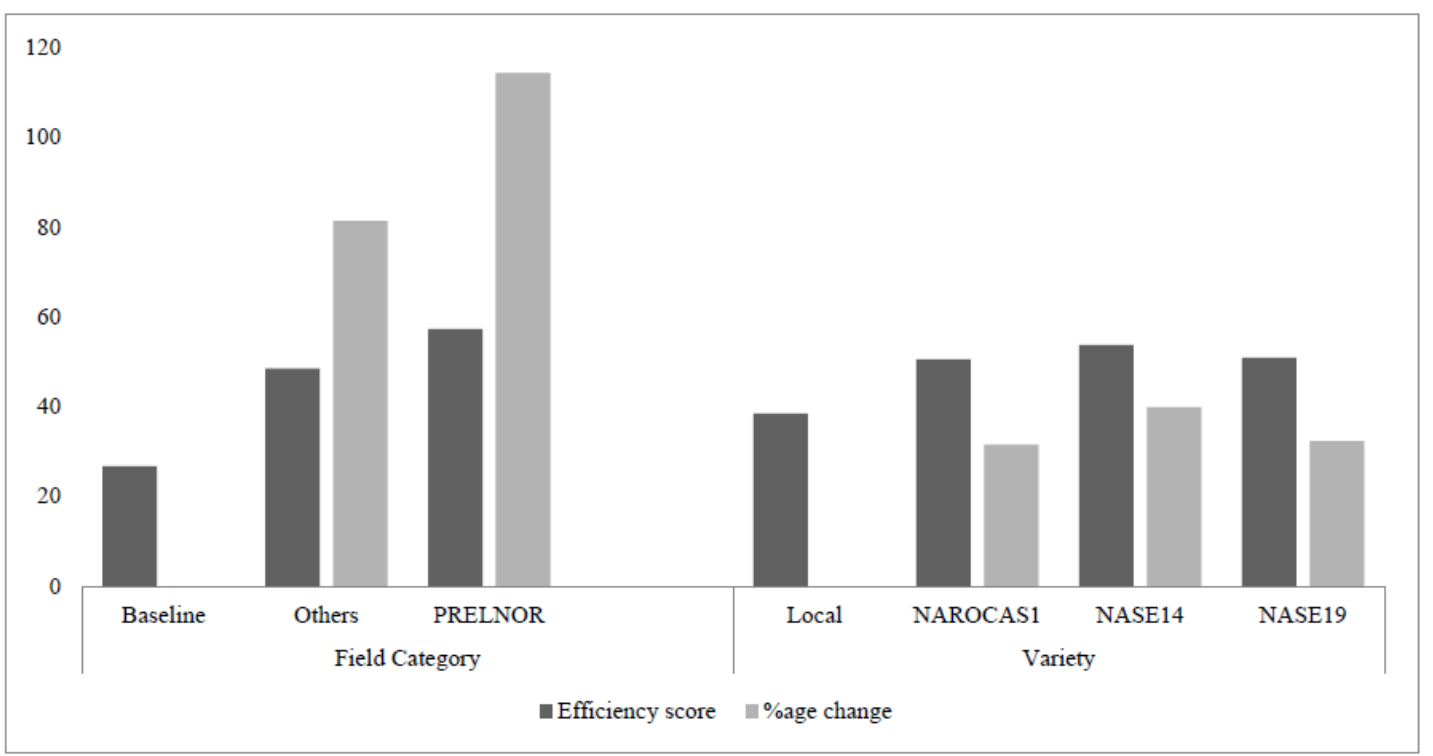

Figure 2. Efficiency gain/loss by field category and variety (\%age)

On average the baseline fields attained mean efficiency of $26.7 \%$ which translated into an inefficiency gap of $73.3 \%$ from the best frontier. Meanwhile other farmers' field registered mean efficiency of $48.4 \%$ representing $81.3 \%$ gain above the baseline. Whereas PRELNOR supported fields registered an average of $57.2 \%$ and in comparison to the baseline fields, there was an improvement (efficiency gain) of $114.2 \%$. These results imply that profit efficiency will improve as farmers gain access to programmes directed towards improving cassava value chain.

Conversely, efficiency performance in terms of varieties revealed poor performance in local variety $(38.4 \%)$ as expected. On the other hand, all the improved varieties performed slightly above average frontier. NASE14 was more efficient at $53.7 \%$ followed by NASE19 (50.8\%) and NAROCAS1 $(50.5 \%)$. According to the growth comparison, efficiency improved by 31.5 to $39.8 \%$ above the local variety. This did not come as a surprise since improved varieties are bred to enhance yields, profit and subsequently income level by addressing challenges such as pest and disease and poor adaptability to bad weather among others which affects yields. Isonguyo \& Omolehin (2017) also found planting material of improved varieties (resistant CMD) more efficient (1.0) than non-improved varieties (1.15) among Nigerian farmers. Relatedly, Akerele et al. (2019) reported mean technical of $58.6 \%$ and concluded that there was room for improvement by $41.4 \%$ and that cassava production in the study area is very lucrative. Eze \& Nwibo (2014) observed that cassava production was profitable but farmers were inefficient because they were underutilizing resources. Planting material and labour were underutilized with efficiency index of 3.1 and 6.3, respectively implying that income can only be improved by using resources efficiently.

\section{Conclusion and Recommendation}

\subsection{Conclusions}

This paper concludes that the use of improved varieties increases farmers income by 1.2 to 1.7 times above the local varieties. The study also revealed that lack of information on good agronomic practices and labour constraints affect profitability from cassava growing.

\subsection{Recommendation}

This study recommends further research into biophysical constraints causing yield and profit gaps and the possible solution. The study also recommends increase in investment in promotion of pest and disease tolerant improved varieties by enhancing access to low cost planting materials of improved varieties. There is need to turn the current rate of return into economically viable enterprise through integrated approach throughout the value chain by integrating high-yielding and pest and disease resistant varieties with value addition and marketing. There is need to encourage farmers to upscale production in order to enjoy economies of scale since it 
is economically viable.

\section{Acknowledgement}

This study was funded by the Government of Uganda with a grant from ASAP (Adaptation for smallholder Agricultural Program) and a loan from IFAD through the Project for the Restoration of Livelihood in Northern Region (PRELNOR). We are grateful to farmers in Kitgum, Lamwo, Pader, Agago Amuru and Gulu from whom we collected the data.

\section{Reference}

AgriTT. (n.d.). Building Uganda's cassava production base.

Ajetomobi, J., Abiodun, A., \& Hassan, R. (2011). Impacts of Climate Change on Rice Agriculture in Nigeria. Tropical and Subtropical Agroecosystems, 14(2), 613-622.

Akerele, E. O. (2019). Productivity and Technical Efficiency of Cassava Production in Ogun State, Nigeria.

Akongo, G. O., Gombya-Ssembajjwe, W., Buyinza, M., \& Bua, A. (2016). Effects of Climate Variability on Technical Efficiency of Rice in Acholi and Lango Sub-regions, Uganda. Journal of Economics and Sustainable Development, 7(11). Retrieved from www.iiste.org

Akongo, G. O., Gombya-Ssembajjwe, W., Buyinza, M., \& Namaalwa, J. J. (2018). Characterisation of Rice Production Systems in Northern Agro-Ecological Zone, Uganda. Journal of Agricultural Science, 10(1), 272. https://doi.org/10.5539/jas.v10n1p272

Akongo, O. G., \& Otim, A. G. (2017). Baseline survey report for Project for the Restoration of Livelihoods in Northern Region (PRELNOR). Ngetta Zonal Agricultural and Development Institute. National Agricultural Research Organisation.

Belotti, F., Daidone, S., Ilardi, G., \& Atella, V. (2012b). Stochastic frontier analysis using Stata. Stata Journal, 13(14), 718-758. https://doi.org/10.2139/ssrn.2145803

Buyinza, T., \& Kitinoja, L. (2018). Commodity Systems Assessment of Cassava in Uganda.

Coelli, T. J., Rao, D. S. P., O’Donnell, C. J., \& Battese, G. E. (2005). An Introduction to Efficiency and Productivity Analysis (2nd ed.).

Eze, A. V., \& Nwibo, S. U. (2014). Economic and technical efficiency of cassava production in Ika North East Local Government Area of Delta State, Nigeria. Journal of Development and Agricultural Economics, 6(10), 429-436. https://doi.org/10.5897/jdae2013.0541

Ezeano, C. I., Okeke, C. C., Obiekwe, N. J., \& Onwusika, A. I. (2017). Adoption and profitability of TMS cassava variety Inenugu South Local Government Area Of Enugu State, Nigeria. Indo-Asian Journal of Multidisciplinary Research (IAJMR), 3(3), 1125-1134. https://doi.org/10.22192/iajmr.2017.3.3.3

Hyuha, T. S., Bashaasha, B., Nkonya, E., \& Kraybill, D. (2007). Analysis of Profit Inefficiency in Rice Production in Eastern and Northern Uganda. African Crop Science Journal, 15(4).

Isonguyo, R. G., \& Omolehin, R. A. (2017). Comparative Economic Analysis of Cassava Mosaic Disease-Resistant Varieties and Non-Resistant Varieties Production in Akwa Ibom State of Nigeria. International Journal of Environment, Agriculture and Biotechnology, 2(5), 2605-2621. https://doi.org/10.22161/ijeab/2.5.43

Itam, K. O., Ajah, E. A., \& Agbachom, E. E. (2014). Analysis of Determinants of Cassava Production and Profitability in Akpabuyo Local Government Area of Cross River State, Nigeria. International Business Research, 7(12). https://doi.org/10.5539/ibr.v7n12p128

Itam, K. O., Ajah, E. A., \& Udoeyop, M. J. (2018). Comparative cost and return analysis of cassava production by adopters and non-adopters of improved cassava varieties among farmers in Ibesikpo Asutan LGA, Akwa Ibom State, Nigeria. Global Journal of Agricultural Sciences, 17(1), 33. https://doi.org/10.4314/gjass.v17i1.4

JICA. (2012). The Project for Rural Road Network Development in Acholi Sub-region in Northern Uganda Final Report Vol.2: Main Report. Japanese International Cooperation Agency (JICA).

Kilimo Trust. (2012). Development of Inclusive Markets in Agriculture and Trade (DIMAT): A Value Chain Analysis of the Cassava Sub-sector in Uganda. Undp. Retrieved from http://www.undp.org/content/dam/uganda/docs/UNDPUg_PovRed_ValueChainAnalysisReportHoney2013 Report.pdf 
Kumbhakar, S. C., \& Lovell, C. A. K. (2000). Stochastic Frontier Analysis. Cambridge University Press. https://doi.org/10.1017/cbo9781139174411

NARO. (2018). The NARO Strategic Plan 201819 - 202728, National Agriculture Research organization, Entebbe, Uganda.

Ndonda, A., Mahungu, N., Frangoie, A., \& Moango, A. (2015). Enhancing yield and profitability of cassava in the savannah and forest zones of Democratic Republic of Congo through intercropping with groundnut. Journal of Applied Biosciences, 89(1), 8320. https://doi.org/10.4314/jab.v89i1.6

Okao-Okuja, G., Hamba, S., Omara, J., Nuwamanya, E., Kawuki, R., Alicai, T., \& Hnya, E. K. R. (2017). Cassava applied research for food and income security in Northern Uganda. Cassava baseline survey report.

Omotayo, A. O., \& Oladejo, A. J. (2016). Profitability of Cassava-based Production Systems. Journal of Human Ecology, 56(1-2), 196-203. https://doi.org/10.1080/09709274.2016.11907056

UBOS. (2003). Statistical abstract 2003. Uganda National Bureau of Statistics (UBOS). Retrieved from http://www.ubos.org

UBOS. (2010). Uganda Census of Agriculture 2008/2009 Volume 4: Crop Area and Production Report. Uganda Bureau of Statistics. Retrieved from http://www.ubos.org/

UBOS. (2011). Statistical abstract 2011. Uganda Bureau of Statistics (UBOS). Retrieved from http://www.ubos.org/

UBOS. (2019). Statistical abstract final 2019. Uganda National Bureau of Statistics (UBOS). Retrieved from http://www.ubos.org/

UNMA. (2017). UNMA. (2017). Monthly mean rainfall and temperature for the last ten years collected from weather stations in Lira, Gulu and Kitgu. Uganda National Meteorology Authority (UNMA).

\section{Copyrights}

Copyright for this article is retained by the author(s), with first publication rights granted to the journal.

This is an open-access article distributed under the terms and conditions of the Creative Commons Attribution license (http://creativecommons.org/licenses/by/3.0/). 